\title{
Oral Tolerization to Adenoviral Antigens Permits Long-Term Gene Expression Using Recombinant Adenoviral Vectors
}

\author{
Yaron Ilan, ${ }^{\star \|}$ Renu Prakash, ${ }^{\star \mid}$ Anne Davidson, ${ }^{\star \S}$ Vinod Jona, ${ }^{\star \mid}$ G. Droguett, ${ }^{\S}$ Marshall S. Horwitz, ${ }^{\S}$ Namita Roy Chowdhury, ${ }^{\star \star||}$ \\ and Jayanta Roy Chowdhury**|ศ \\ *Department of Medicine, ${ }^{\ddagger}$ Department of Molecular Genetics, ${ }^{\S}$ Department of Microbiology and Immunology, $"$ Marion Bessin Liver \\ Research Center, and "Seaver Institute of Human Genetics, Albert Einstein College of Medicine, New York 10461
}

\begin{abstract}
Recombinant adenoviruses (Ads) efficiently transfer foreign genes into hepatocytes in vivo, but the duration of transgene expression is limited by the host immune response which precludes gene expression upon readministration of the virus. To test if this immune response can be abrogated by oral tolerization, we instilled protein extracts of a recombinant adenovirus type-5 via gastroduodenostomy tubes into bilirubinUDP-glucuronosyltransferase-1 (BUGT ${ }_{1}$ )-deficient jaundiced Gunn rats. Control rats received BSA. Subsequent intravenous injection $5 \times 10^{9}$ pfu of a recombinant adenovirusexpressing human BUGT $_{1}\left(\mathrm{Ad}-\mathrm{hBUGT}_{1}\right)$ resulted in hepatic expression of human $\mathrm{BUGT}_{1}\left(\mathrm{hBUGT}_{1}\right)$ with reduction of serum bilirubin levels by $70 \%$. After 2 mo serum bilirubin increased gradually. In orally tolerized rats, but not in controls, a second dose of the virus on day 98 markedly reduced serum bilirubin again. In the tolerized rats, the development of antiadenoviral neutralizing antibodies and cytotoxic lymphocytes were markedly inhibited, and transplantation of their splenocytes into naive Gunn rats adoptively transferred the tolerance, indicating a role for regulatory cells. Lymphocytes from the tolerized rats hyperexpressed TGF $\beta_{1}$, IL2, and IL4 upon exposure to viral antigens, whereas IFN $\gamma$ expression became undetectable. Thus, oral tolerization with adenoviral antigens permits long-term gene expression by repeated injections of recombinant adenoviruses. (J. Clin. Invest. 1997. 99:1098-1106.) Key words: oral tolerization • recombinant adenovirus • gene therapy • Gunn rats • UDPglucuronosyltransferase $\bullet$ Crigler-Najjar syndrome type I
\end{abstract}

\section{Introduction}

Recombinant adenoviruses, retroviruses, and adeno-associated viruses are being used by many investigators for somatic gene therapy $(1,2)$. While retroviruses and adeno-associated viruses integrate into the host genome and have been used for ex vivo gene transfer, they require cell division for integration,

Address correspondence to Jayanta Roy Chowdhury, Professor of Medicine and Molecular Genetics, Marion Bessin Liver Research Center, Albert Einstein College of Medicine, 1300 Morris Park Avenue, Bronx, New York 10461. Phone: 718-430-2265; FAX: 718-4308975; E-mail: chowdhur@aecom.yu.edu

Received for publication 26 September 1996 and accepted in revised form 19 December 1996.

J. Clin. Invest.

(C) The American Society for Clinical Investigation, Inc. 0021-9738/97/03/1098/09 \$2.00

Volume 99, Number 5, March 1997, 1098-1106 making them inconvenient for in vivo gene transfer into hepatocytes that are normally quiescent (3). Adenoviruses (Ads) ${ }^{1}$ are nonenveloped double-stranded DNA with a wide host range that can be generated at high titers and are very efficient at transferring foreign genes into nondividing cells (4). After systemic administration, recombinant adenovirus 5 (Ad5) is preferentially localized and expressed in the liver (5). However, the expression of foreign genes delivered by these vectors is of limited duration because of the episomal nature of adenoviruses $(6,7)$, and, more importantly, because of the host humoral and cellular immune response (8). Host cytotoxic lymphocytes (CTL) acting against adenovirally infected cells may clear the adenovirally infected cells, reducing the duration of transgene expression in vivo after the initial injection of the virus. Neutralizing antibodies that appear in response to the initial exposure to adenoviral proteins prevent effective gene transfer to hepatocytes upon reinjection of the virus.

Recombinant adenoviruses are generated by insertion of the target gene into the E1 region of the viral genome, thus disrupting the E1 gene and rendering the virus replication defective (9). Based on the concept that some host cellular proteins may substitute for the missing E1 gene products, thereby resulting in the transcription of the viral genes, attempts have been made to further cripple the adenoviral vector by using a virus containing a mutation in the E2a region that results in the expression of temperature-sensitive DNA binding proteins. However, these second generation adenoviruses are still able to invoke a potent antiviral immune response $(10,11)$. It is likely, therefore, that the antigenic load in the input recombinant virus is sufficient to produce this immune response. Thus other mechanisms of modulating the antiviral immune response need to be sought.

Enteral exposure to foreign antigens has been shown to induce antigen-specific tolerance by clonal inactivation of antigen-specific $\mathrm{T}$ cells or by the induction of regulatory cells secreting factors that suppress the generation of antigen-specific effector cells (12-14). Therefore, we wanted to evaluate whether induction of oral tolerance to adenoviral antigens could be used to abrogate the host antiadenoviral immune response, thereby prolonging virus expression and allowing successful viral readministration.

Our model system employs mutant Gunn rats that lack hepatic bilirubin uridine-diphosphoglucuronate glucuronosyltransferase-1 $\left(\mathrm{BUGT}_{1}\right)$. Gunn rats are an animal model of Crigler-Najjar syndrome type I $(15,16)$. In both the human disease

1. Abbreviations used in this paper: ALT, alanine aminotransferase; CTL, cytotoxic lymphocytes; bBUGT ${ }_{1}$, human bilirubin-UDP-glucuronosyltransferase-1; LacZ, $\beta$-galactosidase gene; pfu, plaque forming units; RT-PCR, reverse transcription-primed PCR. 
and the mutant rats, $\mathrm{BUGT}_{1}$ deficiency is inherited as an autosomal recessive characteristic and results in life-long unconjugated hyperbilirubinemia leading to cerebral toxicity (17-20). The advantage of using Gunn rats for developing gene therapy methods is that the expression of BUGT $_{1}$ can be conveniently evaluated by monitoring serum bilirubin levels (15). In addition, excretion of bilirubin glucuronides in the bile provides unequivocal evidence of BUGT1 expression in vivo.

We used high-dose and low-dose tolerizing regimens to induce oral tolerance to viral antigens. High-dose feeding, which has been shown to induce anergy or deletion of antigen-reactive $\mathrm{T}$ cells, was found to be ineffective. In contrast, oral tolerization with low-dose feeding of adenoviral protein extracts markedly inhibited both the humoral and cellular host immune response to the recombinant adenovirus containing the human BUGT $_{1}$ gene, thereby permitting long-term gene expression and an effective metabolic effect upon repeated administration of the virus. This was achieved by induction of regulatory cells that were able to transfer tolerance to naive animals.

\section{Methods}

\section{Animals}

Inbred Gunn and congenic normal Wistar RHA rats were bred and maintained in the Special Animal Core of the Marion Bessin Liver Center of the Albert Einstein College of Medicine. The rats were maintained on standard laboratory chow and kept in 12-h light-dark cycles.

\section{Plasmids}

pJM17 was kindly provided by Dr. F.L. Graham, (McMaster University, Hamilton, Canada). Adeno- $\beta$-galactosegene (Ad-LacZ) virus was obtained through the courtesy of Dr. M. Imperiale, (University of Michigan, Ann Arbor, MI).

\section{Generation of recombinant adenovirus}

Two recombinant adenoviruses, Ad-human bilirubin-UDP-glucuronosyltransferase-1 (hBUGT ${ }_{1}$ ) and Ad-LacZ-expressing $\mathrm{hBUGT}_{1}$, and Escherichia coli $\beta$-galactosidase, respectively, were generated as described previously (5). In brief, transcription units consisting of the promoter and enhancer sequence for the immediate early gene of cytomegalovirus (CMV), the structural region of human $\mathrm{BUGT}_{1}$ or $E$. coli $\beta$-galactosidase, and the polyadenylation signal from bovine growth hormone were recombined into the $\mathrm{E} 1$ region of human Ad-5 to produce replication-defective first generation adenoviruses. For largescale preparation, the recombinant adenoviruses were grown on 293 suspension cells and purified from cell lysates by two consecutive $\mathrm{CsCl}$ density gradient centrifugations, and stored in $30 \%$ glycerol at $-20^{\circ} \mathrm{C}$. The virus was dialyzed overnight at $4^{\circ} \mathrm{C}$ against an isotonic solution containing $135 \mathrm{mM} \mathrm{NaCl}, 5 \mathrm{mM} \mathrm{KCl}, 1 \mathrm{mM} \mathrm{MgCl}, 10 \mathrm{mM}$ Tris$\mathrm{HCl}, \mathrm{pH} 7.4$, and $10 \%$ glycerol, and sterilized by filtration through $0.45-\mu \mathrm{m}$ filters before use (5).

\section{Preparation and administration of viral protein extracts}

The $\mathrm{CsCl}$ gradient supernatant, containing major adenoviral structural proteins, mainly fiber, hexon, and penton, was collected and the protein concentration was determined $(21,22)$. Under ether anesthesia, a polyethelene cathether (PE10) was inserted into the stomach through a midline incision. The tube was advanced into the duodenum and affixed to the stomach wall. The other end of the catheter was exteriorized at the dorsal aspect of the neck by subcutaneous tunneling. Each of the rats was kept in a separate cage throughout the study. The protein extracts were introduced through the catheter every other day for $21 \mathrm{~d}$ (a total of 11 doses).

\section{$A d-h B U G T_{1}$ and $A d-L a c Z$ injection into Gunn rats}

Five groups of Gunn rats, consisting of 10 animals in each group, were studied. Groups A and B included rats that were fed with adenovirus protein extract at a dose of $1 \mathrm{mg} / \mathrm{rat}$ every other day followed by two injections of Ad-hBUGT $1\left(5 \times 10^{9} \mathrm{pfu}\right)$ on days 1 and 98 (group A), or Ad-hBUGT 1 on day 1 followed by Ad-LacZ on day 98 (group B). Two groups of rats were used as controls: group $\mathrm{C}$ received BSA $1 \mathrm{mg} / \mathrm{d}$ and then received viral injections as described for group A (5 rats, group C1) or for group B (5 rats, group C2). Group D did not receive any oral proteins and was injected with AdhBUGT $_{1}$ similarly to group A (Table I). In order to evaluate the mechanism of the tolerance and to distinguish between induction of suppressor cells and clonal inactivation group $\mathrm{E}$ rats were fed with 50 $\mathrm{mg} / \mathrm{d}$ (5 rats), or $100 \mathrm{mg} / \mathrm{d}$ (5 rats) of the viral protein extract (high dose regimen), followed by two injections of Ad-hBUGT . $_{1}$

\section{Assessment of transgene expression}

$\beta$-Galactosidase expression. Gunn rats from groups that received Ad-hBUGT $_{1}$ as the first injection and Ad-LacZ as the second injection with (group B) or without (group C2) previous administration of adenoviral proteins underwent liver biopsies. Specimens were frozen in Tissue Freezing Medium (Triangle Biomedical Sciences, Durham, NC), in a dry ice-cooled methyl butane bath. Frozen cryostat sections $(10 \mu \mathrm{m})$ were fixed for $5 \mathrm{~min}$ at room temperature in freshly prepared $1 \%$ glutaraldehyde in PBS. $\beta$-Galactosidase activity was detected by immersing the section into 5-bromo-4-chloro-3-indol- $\beta$-galactopyranoside (X-Gal) staining solution $\left(5 \mathrm{mM} \mathrm{K}{ }_{4} \mathrm{FeCN}, 5 \mathrm{mM} \mathrm{K}{ }_{3} \mathrm{FeCN}, 1 \mathrm{mM}\right.$ $\mathrm{MgCl}_{2}$, containing $1 \mathrm{mg}$ of $\mathrm{X}-\mathrm{Gal} / \mathrm{ml}$ ) for $8-15$ hours at $37^{\circ} \mathrm{C}$. Sections were briefly counterstained with eosin, then dehydrated and mounted.

$D N A$ analysis using PCR. To detect the presence of the human BUGT $_{1}$ gene in the host liver, DNA was extracted from RNase treated tissue homogenates as described previously (23). Two rats from each of the experimental groups $\mathrm{A}$ and $\mathrm{E}$, and the control groups $\mathrm{C} 1$ and $\mathrm{D}$, were tested $3 \mathrm{~d}$ after the second $\mathrm{Ad}-\mathrm{hBUGT} \mathrm{T}_{1}$ injection. DNA was subjected to amplification by PCR using primers (sense: 5'AAGGAAAGGGTCCGTCAGCA 3' from nucleotide 141 to nucleotide 160; antisense: 5'CCAGCAGCTGCAGCAGAGG 3'

Table I. Experimental Groups

\begin{tabular}{llll}
\hline Group & \multicolumn{1}{c}{ Antigen fed and dose } & $\begin{array}{c}\text { Recombinant virus injected } \\
\text { on first injection }\end{array}$ & $\begin{array}{c}\text { Recombinant virus injected } \\
\text { on second injection }\end{array}$ \\
\hline A & Adenoviral proteins: $1 \mathrm{mg} / \mathrm{rat} / \mathrm{d}$ & Ad-hBUGT $_{1}$ & $\begin{array}{c}\text { Ad-hBUGT } \\
\text { Ad-LacZ } \\
\text { Bd-hBUGT }\end{array}$ \\
B & Adenoviral proteins: $1 \mathrm{mg} / \mathrm{rat} / \mathrm{d}$ & Ad-hBUGT $(5 \mathrm{rats})$ \\
C & BSA: $1 \mathrm{mg} / \mathrm{rat} / \mathrm{d}$ & Ad-hBUGT $_{1}$ & Ad-LacZ (5 rats $)$ \\
D & None & Ad-hBUGT $_{1}$ & Ad-hBUGT $_{1}$ \\
E & Adenoviral proteins: $50 \mathrm{mg} / \mathrm{rat} / \mathrm{d}$ & & Ad-hBUGT $_{1}$ \\
& $(n=5)$, or $100 \mathrm{mg} / \mathrm{rat} / \mathrm{d}(n=5)$ & Ad-hBUGT $_{1}$ & \\
\hline
\end{tabular}


from nucleotide 441 to nucleotide 462 ) designed to amplify a 321-bp segment of the the unique exon 1 (exon $1 * 1$ ) of the $\mathrm{hBUGT}_{1}$ gene. PCR amplification was performed using the following protocol: $94^{\circ} \mathrm{C}$ for $30 \mathrm{~s}, 58^{\circ} \mathrm{C}$ for $30 \mathrm{~s}$, and $72^{\circ} \mathrm{C}$ for $1 \mathrm{~min} \times 30$ cycles.

Expression of $h B U G T_{1}$ protein. For determination of the expression of $\mathrm{hBUGT}_{1}$, liver specimens were taken from two rats in experimental group A and control group $\mathrm{C} 15 \mathrm{~d}$ after the second viral injection. Tissue homogenates $(200 \mathrm{mg} / \mathrm{ml})$ were prepared in $0.25 \mathrm{M}$ sucrose $/ 10 \mathrm{mM}$ Tris-HCl, $\mathrm{pH} 7.4$, using a glass homogenizer fitted with a motor-driven teflon pestle. For immunoblot analysis, proteins (100 mg/lane) were resolved by electrophoresis on SDS-polyacrylamide $(7.5 \%)$ gels and electroblotted to nitrocellulose membranes. The membranes were probed with a monoclonal antibody WP1 directed at the common carboxyterminal domains of UGT isoforms expressed by $\mathrm{hBUGT}_{1}$, followed by peroxidase conjugated goat antimouse IgG F'ab fragment second antibody (Sigma Chemical Co., St. Louis, MO) and substrate $(24,25)$. Equal protein loading in all lanes was assured by performing the electroporesis on an identical SDSpolyacrylamide gel and staining the protein bands with Coomassie brilliant blue.

Assay for $B U G T_{1}$ activity towards bilirubin. The enzyme assay was performed on homogenates of liver specimens from two rats from each experimental group that received Ad-hBUGT ${ }_{1}$ injection (A, E, $\mathrm{C} 1$, and $\mathrm{D}$ ), $20 \mathrm{~d}$ after the first and second injection, and from all other rats at the termination of the experiments. The assay method was as previously described, using $80 \mu \mathrm{M}$ bilirubin as the aglycone $(26,27)$.

Determination of serum bilirubin levels. Serum bilirubin levels were measured according to Jendrasik and Grof in all groups every 10-14 d throughout the study period (26).

Bile pigment analysis. For definitive demonstration of bilirubin glucuronidation in selected rats, bile was collected through a polyethylene bile duct cannula and bilirubin glucuronide excreted in bile was analyzed by HPLC using a $\mu$ Bondapak C- 18 column (Millipore-Waters, Milford, MA) as described previously (27). Bile was analyzed in two rats from experimental groups that received adenoviral proteins at 1 $\mathrm{mg} / \mathrm{d}$ (group A), $50 \mathrm{mg} / \mathrm{d}$, or $100 \mathrm{mg} / \mathrm{d}$ (group E), BSA $1 \mathrm{mg} / \mathrm{d}$ (groups C1), or no protein at all (D), $20 \mathrm{~d}$ after the first and second injections of the recombinant adenovirus. All other rats had bile pigment analysis at the termination of the experiments.

\section{Evaluation of immune tolerance}

Liver histology. For evaluation of the degree of hepatic inflammation, liver biopsies were performed $1 \mathrm{wk}$ after the second injection in two rats from each of the treated groups and kept in $10 \%$ formaldehyde. Paraffin sections were then stained with hematoxylin-eosin according to standard procedures. The sections were graded for hepatic inflammation as follows: grade 0 , normal; grade 1 , mild periportal or focal lobular lymphocytic infiltration; grade 2, extension of lymphocytic infiltration into the lobules and "piece-meal" necrosis; and grade 3 , disruption of the lobular architecture by "bridging" necrosis and extension of lymphocytic infiltrates from portal-to-central, portal-to-portal, and central-to-central zones.

Serum alanine amino transferase $(A L T)$ levels. As a measure of the degree of hepatic inflammation, ALT levels were quantified using a commercially available kit (Sigma Chemical Co.).

Neutralizing antiadenoviral antibodies. Antiadenoviral neutralizing antibodies present in the sera of treated rats were measured on days $28,78,112$, and 196 in all rats that received Ad-hBUGT injec- $_{1}$ tion. 293 cells were seeded at a concentration of $3 \times 10^{4} /$ well in 96well plates, and cultured until $90 \%$ confluency. Ad-LacZ was diluted in cell culture medium to give $3 \times 10^{5} \mathrm{pfu} / 10 \mathrm{ml}$. Serum samples were heat inactivated at $55^{\circ} \mathrm{C}$ for $30 \mathrm{~min}$ and diluted in medium in twofold steps. $100 \mu \mathrm{l}$ of each serum dilution was mixed with $5 \times 10^{5}$ pfu of the recombinant virus, incubated at $37^{\circ} \mathrm{C}$ for $90 \mathrm{~min}$, and applied to the nearly confluent 293 cells for $10-14 \mathrm{~h}$. The supernatant containing serum and virus was then replaced by RPMI medium with $10 \%$ FCS for $18 \mathrm{~h}$. Cells were fixed and stained for $\beta$-galactosidase expression. In the absence of neutralizing antibodies all of the cells stained blue. The neutralizing antibody titer for each serum sample was reported as the highest dilution at which less than $25 \%$ of the cells stained blue.

Cytotoxic T lymphocyte assay. Two rats from each group were studied on days $28,78,112$, and 196 . Spleens were removed under anesthesia from each of two rats at each time point, and the animals resutured. The organs were gently disrupted using a rubber policeman. Red blood cells were removed using lysis buffer containing $0.17 \mathrm{M}$ $\mathrm{NH}_{4} \mathrm{Cl}$ at $\mathrm{pH} 7.4(1 \mathrm{ml} /$ spleen $)$ for $2 \mathrm{~min}$. Lymphocytes were spun down and plated at $5 \times 10^{7}$ cells $/ 5 \mathrm{ml}$ in RPMI medium with $10 \%$ FCS. Cells were then restimulated with the recombinant adenovirus Ad-hBUGT 1 (1-10 pfu/cell) for 4-5 d. Adenovirus-infected primary hepatocytes, harvested by collagenase perfusion of the liver (28), were used as target cells for the effector lymphocytes and were plated on collagen-coated 6-well plates in Chee's medium $\left(2 \times 10^{6}\right.$ cells/ well). Stimulated effector cells were harvested, counted, and added to the primary hepatocyte cultures at a ratio of 50-100:1 and incubated at $37^{\circ} \mathrm{C}$ for $5 \mathrm{~h}$. Hepatic cell lysis was measured by collecting the medium and measuring ALT levels using a commercially available kit (Sigma Chemical Co.) with the following modifications: the ratio between reagent and test medium was changed from 10:1 to $1: 1$, and the reaction time before the first spectrophotometric reading was $90 \mathrm{~s}$, followed by a reading every $30 \mathrm{~s}$ up to $5 \mathrm{~min}$. ALT levels were then calculated according to the manufacturer's formula and expressed in international units. Background ALT levels were determined by measurements of the ALT levels in the supernatants of dishes containing adenovirally infected hepatocytes and lymphocytes from naive rats. CTL activity was expressed in IU of ALT averaged from 6 wells after subtraction of background levels.

\section{Evaluation of the mechanism of oral tolerance}

Serum TGF $\beta 1$ levels. TGF $\beta 1$ levels were measured by a sandwich ELISA using Genzyme Diagnostics kit according to the manufacturer's instructions. Serum TGF $\beta 1$ levels were measured in three rats from each group after each injection, on days 8 and 101.

$T G F \beta 1$ secreted by intestinal lymphocytes and splenocytes. Extraction of gut wall lymphocytes was performed as previously reported (29). In brief, the small intestines were removed from two rats each from the tolerized and the control groups on day 101, and placed in RPMI medium supplemented with $15 \%$ FBS. The intestines were cut into $1-\mathrm{cm}$ segments, flushed with the medium, opened by cutting longitudinally, transferred into fresh medium, rinsed four times with PBS, and placed in PBS (calcium and magnesium free) containing $1 \mathrm{mM}$ EDTA and $1 \mathrm{mM}$ DTT. Fragments were stirred for $30 \mathrm{~min}$ at $37^{\circ} \mathrm{C}$ and the exfoliated cells were harvested by decanting the PBS after tissue fragments had settled. Cells were passed through nylon wool, pelleted by centrifugation for $5 \mathrm{~min}$, suspended in $10 \mathrm{ml}$ of $40 \%$ Percoll, and layered over a cushion of $70 \%$ Percoll. Cells were then centrifuged for $20 \mathrm{~min}$ at $600 \mathrm{~g}$ and the gut wall lymphocytes at the $70 \%-$ $40 \%$ interface were harvested.

For enrichment of antigen presenting cells, lymphocytes were harvested from the spleens as described above. Cells were then suspended in $4 \mathrm{ml}$ of RPMI containing 5\% FBS and $4 \mathrm{ml}$ of RPMI containing 5\% FBS and $14.5 \mathrm{~g} \%$ metrizamide. After centrifugation at $1,800 \mathrm{~g}$ for $20 \mathrm{~min}$, at room temperature, the interface containing an enriched population of macrophages and dendritic cells was collected.

For determination of TGF $\beta 1$ secretion after each injection, intestinal wall or splenic lymphocytes from untreated Gunn rats, from rats in control groups $\mathrm{C}$ and $\mathrm{D}$, and rats from the tolerized group $\mathrm{A}$-on days 8 and 101 (two rats from each group) -were plated on tissue culture dishes $\left(5 \times 10^{6} / 10\right.$-cm plate $)$ and grown in serum-free media. $1 \times$ $10^{6}$ antigen presenting cells were added per plate along with $50 \mu \mathrm{g}$ of adenoviral protein extracts as the activating antigen. After $72 \mathrm{~h}$ of culturing, TGF $\beta 1$ secreted into the media was quantified by ELISA as described above.

Reverse transcription-primed (RT)-PCR for rat cytokine mRNAs. These assays were performed on day 101 on two rats from each of 
groups A, C, D, and E. After culturing the lymphocytes with the viral antigens and antigen presenting cells as described above, cells were harvested, and mRNA levels for rat IL- $2,-4,-6,-10$, IFN- $\gamma$, and TGF- $\beta 1$ were determined by RT-PCR using amplimers as described before (23). $1 \mu \mathrm{g}$ of RNA was used as template for each sample. Amplimers for rat glyceraldehyde-3-phosphate dehydrogenase (GPDH) were used as an internal control for the RT-PCR.

Adoptive transfer of tolerance. To determine whether the intestinal wall or splenic lymphocytes from the tolerized rats is capable of producing tolerance upon transplantation into naive rats, donor rats from groups $\mathrm{A}$ and $\mathrm{C} 1$ (two rats from each group) were killed at the end of the experiment and single suspensions of lymphocytes derived from the spleen or the small intestine were prepared as described above. The cells were resuspended in PBS immediately before transplantation. Recipient rats were sublethally irradiated with 600 rad total body irradiation, $24 \mathrm{~h}$ before intravenous injection of $5 \times 10^{7}-1 \times$ $10^{8}$ donor cells in $0.5 \mathrm{ml}$ PBS. A total of eight rats were studied; four received the cells from group A donor rats, and four from group $\mathrm{C}$ rats (in each group, two rats received donor splenocytes, $5 \times 10^{8}$ cells, and two received donor gut wall lymphocytes, $5 \times 10^{7}$ cells). All rats were injected with Ad-hBUGT 1 twice, $1 \mathrm{~d}$ after cell transplantation and $98 \mathrm{~d}$ later. Serum bilirubin levels, pigments excreted in bile and antiadenoviral cellular, and humoral immune responses were determined as described before.

\section{Results}

\section{Expression of $\beta$-galactosidase activity}

For histochemical staining, liver biopsies were performed, $7 \mathrm{~d}$ after Ad-LacZ injection from liver specimens of Gunn rats that received Ad-hBUGT ${ }_{1}$ as the first injection and Ad-LacZ as the second injection with (group B) or without (group C2) prior administration of adenoviral proteins. Biopsies were performed on two rats in each group. Histochemical staining of cryostat sections $(10 \mu \mathrm{m})$ showed that the great majority of hepatocytes stained positive for $\beta$-galactosidase activity after the injection in rats that had been administered the adenoviral proteins (group B), while only $5 \%$ of hepatocytes stained positive, in livers from rats that were given BSA (group C2; Fig. 1).

\section{Expression of $h-B U G T_{1}$ gene after recombinant adenoviral} injection into Gunn rats

$D N A$ analysis using PCR. Presence of $\mathrm{hBUGT}_{1}$ DNA in the liver of Gunn rats that received Ad-hBUGT 1 with (group A) or without (groups $\mathrm{C} 1$ and D) prior enteral administration of adenoviral proteins was evaluated by PCR after the second Ad-hBUGT 1 injection. A DNA fragment of $321 \mathrm{bp}$ was seen only in rats from group $\mathrm{A}$, while both control groups $\mathrm{C}$ and $\mathrm{D}$ were negative. Normal human liver and liver from an untreated Gunn rat were used as positive and negative controls, respectively (not shown).

Expression of $h B U G T_{1}$ protein. Liver specimens were collected from two rats in groups $\mathrm{A}$ and $\mathrm{C} 1,5 \mathrm{~d}$ after the second Ad-hBUGT 1 injection. Immunoreactive 52-kD bands, corresponding to $\mathrm{hBUGT}_{1}$ were observed in Gunn rats that were given two injections of Ad-hBUGT 1 after the administration of adenoviral antigens (group A) but not in the group that received the virus injections after enteral administration of BSA (group C; Fig. 2). Normal human liver and untreated Gunn rat livers were used as positive and negative controls, respectively.

$B U G T_{1}$ activity in vitro. UGT activity toward bilirubin was undetectable in untreated Gunn rats. In homogenates of normal human specimens obtained from cadaver donor organs, the $\mathrm{BUGT}_{1}$ activity was $78 \pm 26 \mathrm{nmol} / \mathrm{mg}$ liver wt/min; (mean $\pm \mathrm{SEM}$,

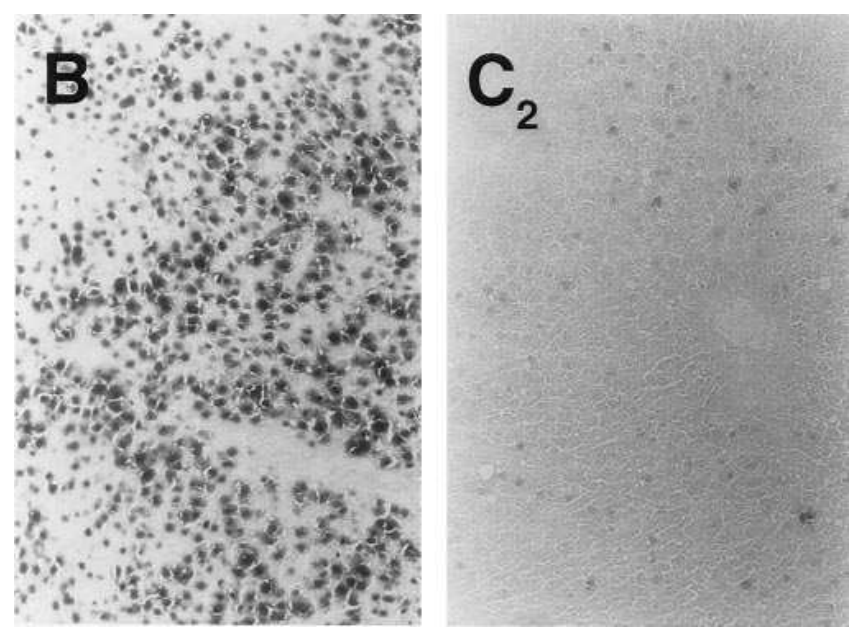

Figure 1. $\beta$-Galactosidase expression in liver specimens from orally tolerized (group B) and control group $\left(\mathrm{C}_{2}\right)$ after the second injection of the recombinant virus.

$n=6)$. In liver homogenates from two rats that received AdhBUGT $_{1}$ injections after enteral administration of adenoviral proteins (group A), bilirubin-UGT activity was 80 and 85 $\mathrm{nmol} / \mathrm{mg}$ liver wet wt/min, $20 \mathrm{~d}$ after the first Ad-hBUGT ${ }_{1}$ injection, and was $88 \pm 20 \mathrm{nmol} / \mathrm{mg}$ liver wet $\mathrm{wt} / \mathrm{min}$ (mean $\pm \mathrm{SEM}$, $n=5) 20 \mathrm{~d}$ after the second injection. In the BSA-fed rats (groups $\mathrm{C} 1$ and D), bilirubin-UGT activity was undetectable after the second injection of Ad-hBUGT . $_{\text {. }}$

Serum bilirubin levels. Bilirubin levels were measured every 10-14 d. A marked decrease in bilirubin levels occurred after each Ad-hBUGT 1 injection in Gunn rats that were tolerized by the administration of adenoviral proteins (group A), with levels reaching as low as 1.83 and $1.78 \mathrm{mg} / \mathrm{dl}$ after the first and second injections, respectively (Fig. 3). Bilirubin levels remained low for over 3 mo after each injection, and then increased gradually. In contrast, in BSA-fed Gunn rats (groups $\mathrm{C}$ and D) the first Ad-hBUGT 1 injection reduced serum bilirubin levels to $2.73 \mathrm{mg} / \mathrm{dl}$ for only $4 \mathrm{wk}$, followed by a progressive increase to preinjection levels. Subsequent Ad-hBUGT injections had no effect on serum bilirubin concentrations in these groups.

Bile pigment analysis. HPLC analysis of bile collected from

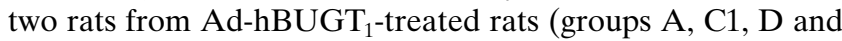
E) $20 \mathrm{~d}$ after the first injection of Ad-hBUGT 1 showed excretion of bilirubin mono- and diglucuronide. The two glucuronides accounted for more than $95 \%$ of the bile pigments, less than $5 \%$ being unconjugated bilirubin. This profile was similar to that seen in normal Wistar rats. A similar pattern was seen

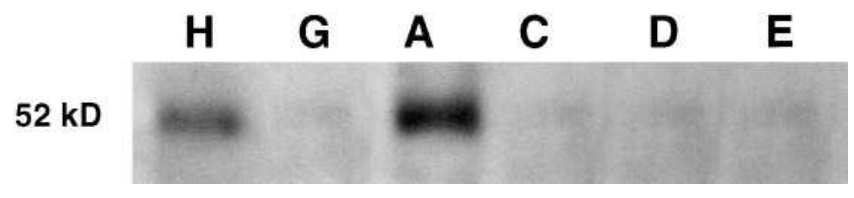

Figure 2. Expression of hBUGT $\mathrm{h}_{1}$ protein. Western blots of liver homogenates prepared $3 \mathrm{~d}$ after the second Ad-hBUGT ${ }_{1}$ injection from rats in group $\mathrm{A}, \mathrm{C}, \mathrm{D}$, and $\mathrm{E}$. Positive control was normal human liver $(H)$; negative control was untreated Gunn rat $(G)$. 52-kD bands were seen only in rats from group A. 
in rats tolerized by enteral administration of $1 \mathrm{mg} / \mathrm{d}$ adenoviral proteins (group A) $20 \mathrm{~d}$ after the second Ad-hBUGT injec- $^{-}$ tion. In rats that received BSA (group C), no protein (group D) or high doses of adenoviral proteins (50-100 mg/d, group E), bile pigment analysis after the second Ad-hBUGT injection $_{1}$ did not show significant amounts of conjugated bilirubin in the bile (Fig. 4). Gunn rats injected with Ad-LacZ did not excrete bilirubin glucuronides in bile. Chromatographic profiles in bile from these rats resembled that from untreated Gunn rats.

\section{Evaluation of immune tolerance}

Liver histology. Liver biopsies from two rats in each group examined 24-72 h after the second injection showed minimal or no periportal or lobular lymphocytic infiltration in recipients that were tolerized by enteral administration of adenoviral proteins (group A). In contrast, a severe inflammatory reaction (grade 3) was observed in liver specimens taken from rats that were given BSA or no protein before the injection of the virus (groups $\mathrm{C}, \mathrm{D}$ ) and rats that received high doses of adenoviral antigens (group E; not shown).

Serum ALT levels. In the group A rats that were tolerized with adenoviral proteins, serum ALT levels increased only minimally after each of the three injections (96-110 IU; normal levels before any manipulation were 60-75 IU). In groups that received BSA or no protein (C and D), ALT levels increased to $168 \mathrm{IU}$ after the first injection, and to $212 \mathrm{IU}$ after the second injection.

Neutralizing antibodies. After injection of Ad-hBUGT ${ }_{1}$ in rats that had received BSA or no proteins, (groups $\mathrm{C}$ and $\mathrm{D}$, respectively), high titer $(>1: 2,816)$ antibodies appeared dur-

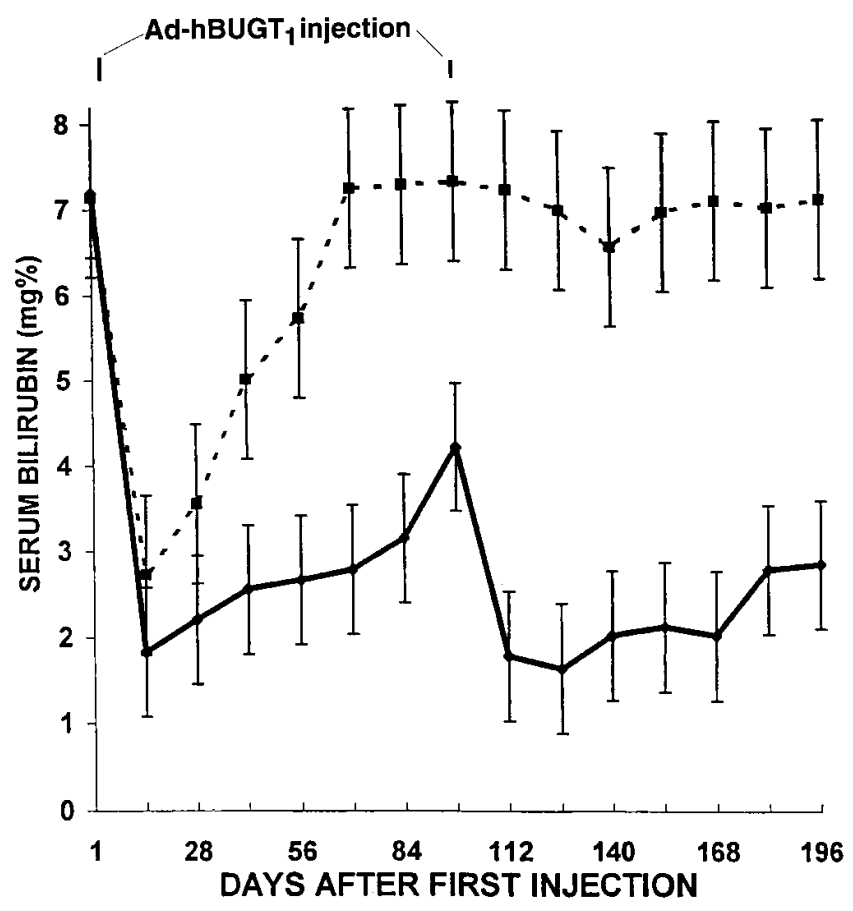

Figure 3. Effect of tolerization on serum bilirubin levels. Rats from Group A (solid line) who received Ad-hBUGT ${ }_{1}$ injections on $\mathrm{d} 1$ and 98 , were compared with rats from group $\mathrm{C} 1$ (dashed line) who received Ad-hBUGT ${ }_{1}$ injections on the same days, but were not fed with the adenoviral antigens (group D rats had similar results to group $\mathrm{C} 1$, data not shown). ing the first month. In contrast, in the tolerized rats (group A), neutralizing antibodies were undetectable in $80 \%$ of the recipients. The remainder exhibited low titers of the antibody $(<1: 16)$ (Fig. 5). Rats that developed the low titer antibodies had similar hypobilirubinemic responses to the second injections of Ad-hBUGT ${ }_{1}$ as did the rats that had no detectable antibodies.

Cytotoxic T lymphocyte response. Cytotoxic $\mathrm{T}$ cells were tested against adenovirus infected rat hepatocytes four times throughout the study. Measurement of the amount of ALT released from the hepatocyte targets into the media was used to assess the CTL response. ALT levels in the media were below $80 \mathrm{IU}$ in all tolerized recipients (groups $\mathrm{A}$ and B), but exceeded 450 IU in nontolerized rats (groups B and C; Fig. 6).
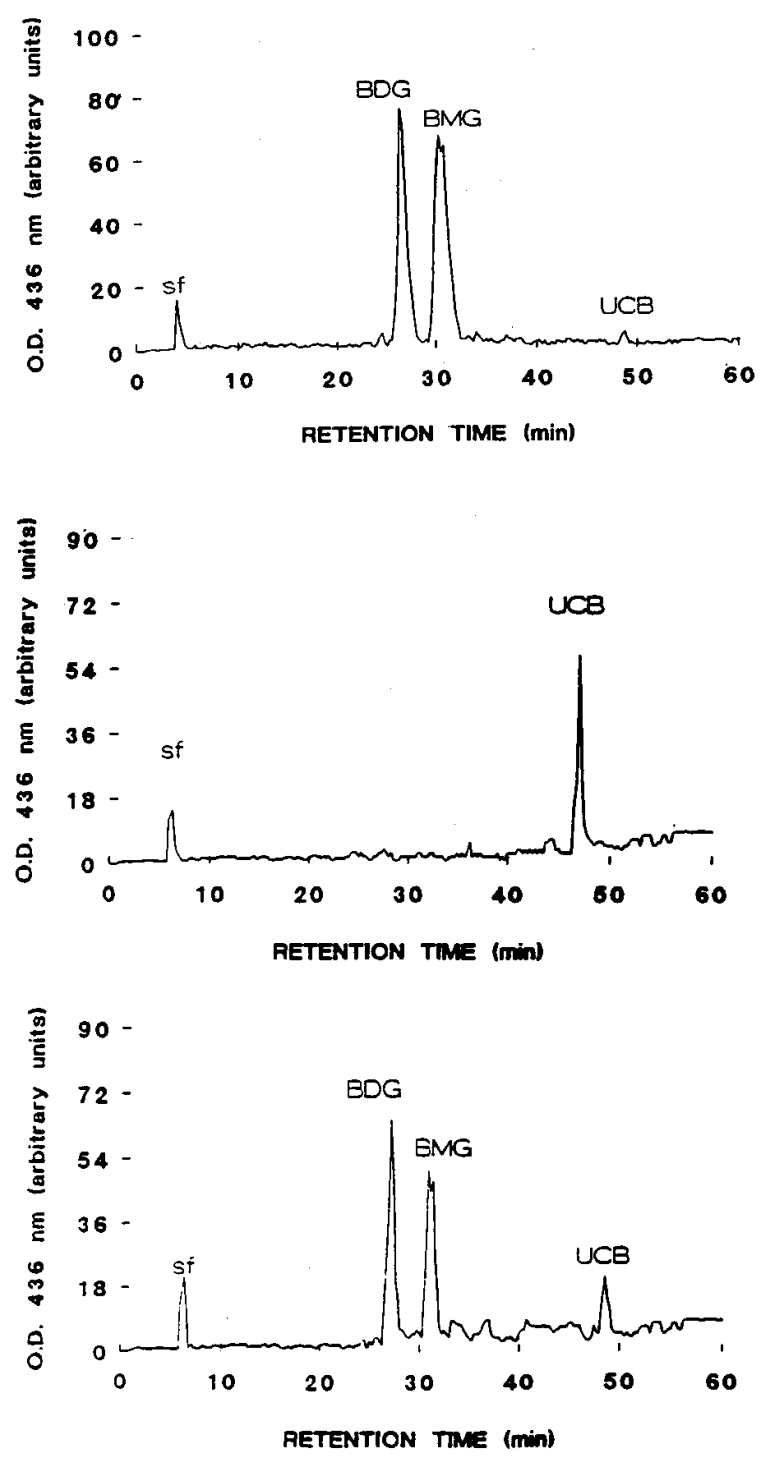

Figure 4. HPLC analysis of bile pigments. Bile was collected from rats from groups A and $\mathrm{C} 120 \mathrm{~d}$ after the second Ad-hBUGT ${ }_{1}$ injection. The upper panel shows a normal rat where above $95 \%$ of the bilirubin in the bile is conjugated (BDG and BMG). The middle panel represents the bile analysis of a Gunn rat from control group $\mathrm{C} 1$ showing mainly unconjugated bilirubin (UCB). The lower panel shows the analysis of bile from a tolerized rat from group A showing that most of the bilirubin is conjugated. (BMG, bilirubin mono glucoronide; BDG, bilirubin di glucoronide; UCB, unconjugated bilirubin). 


\section{The mechanism of oral tolerance}

Serum $T G F \beta_{1}$ concentrations and $T G F \beta_{1}$ secretion in vitro. Serum TGF $\beta_{1}$ levels were increased to $>170 \mathrm{ng} / \mathrm{ml}$ after each injection of the recombinant adenovirus in rats that were given the $1 \mathrm{mg} / \mathrm{d}$ dose of adenoviral proteins before the injection of recombinant viruses (group A). In rats that received BSA or no protein before the virus injection (groups $C$ and D) serum TGF $\beta_{1}$ levels were $30-35 \mathrm{ng} / \mathrm{ml}(P<0.005)$. The levels in normal untreated Gunn rats are $18-26 \mathrm{ng} / \mathrm{ml}$.

In vitro assays for evaluation of $\mathrm{TGF}_{1}$ levels after exposure of splenocytes and gut wall lymphocytes to adenoviral antigens were done in two rats from each group after each virus injection. Low levels $(>4 \mathrm{ng} / \mathrm{ml})$ of TGF $\beta_{1}$ were present in the supernatant of splenocytes and gut wall lymphocytes cultures from the rats that were administered BSA or no protein (group C and D); similar levels of TGF $\beta_{1}$ were observed using gut wall lymphocytes from tolerized rats (normal levels: 2.1$3.6 \mathrm{ng} / \mathrm{ml}$ ). In contrast, splenocytes from rats tolerized by feeding adenoviral proteins (group A) secreted significantly greater amounts of $\mathrm{TGF}_{1}(24-26 \mathrm{ng} / \mathrm{ml})$ after exposure to viral proteins.

$R T$-PCR for rat cytokines. RT-PCR was performed on days 8 and 101 on RNA extracted from and gut wall lymphocyte cell cultures from the various groups. Positive bands for IL-2, $-4,-10$, and TGF $\beta_{1}$ were found in splenocytes from rats tolerized by adenoviral protein administration (group A), but not from rats that had received BSA or no protein at all (groups $\mathrm{C}$ or D). Gut wall lymphocytes cell cultures from the tolerized rats (group A), as well as from rats that received BSA or no proteins (groups $\mathrm{C}$ or $\mathrm{D}$ ), were negative for these cytokine mRNAs. In contrast, IFN $\gamma$ was negative by RT-PCR in splenocytes from the tolerized rats in group $\mathrm{A}$, but was found in splenocytes from rats from control groups $\mathrm{C}$ and D. Gut wall lymphocytes showed similar results to nontolerized rats. IL-6 was detected in all tested groups and probably behaves as a nonspecific acute-phase reactant (Fig. 7).

Effect of antigen dose. To evaluate the relationship between the dose of adenoviral proteins and induction of tolerance, 10 rats in group $\mathrm{E}$ were fed with the viral proteins at higher doses (50-100 mg/d). In these rats serum bilirubin levels and HPLC analysis of pigments excreted in bile indicated that

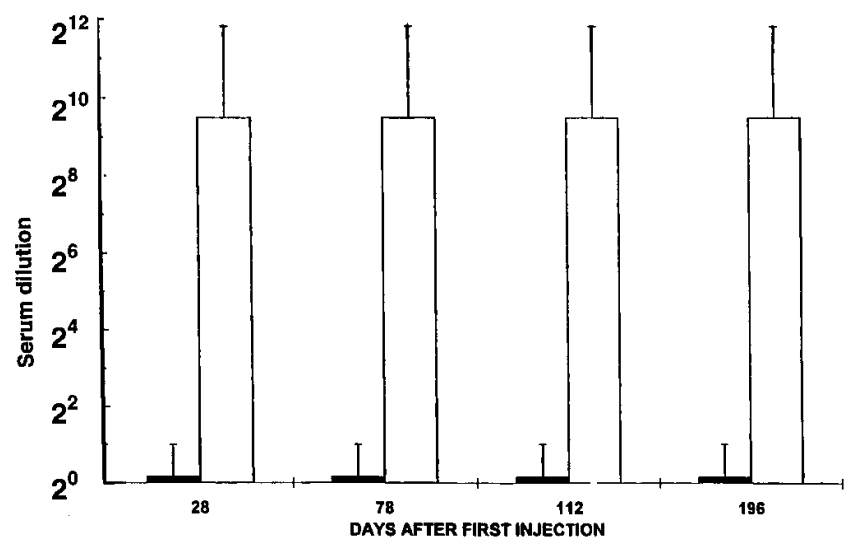

Figure 5. Antiadenovirus neutralizing antibodies levels in group A tolerized (solid bars) and group C control rats (open bars), after the first and second Ad-hBUGT 1 injections. Mean levels were calculated from levels in antibody producing rats. the second recombinant adenoviral injection failed to achieve gene expression or a metabolic effect. The antiadenovirus immune response in this group was similar to that in rats that were administered BSA or no protein at all (groups C and D). Similarly, RT-PCR of RNA extracted from both splenocytes and gut wall lymphocytes from these rats were positive for IFN $\gamma$ and negative for IL-2, IL-4, IL-10, and TGF $\beta_{1}$, as in the case of control nontolerized rats. Thus no evidence for tolerance was observed using higher doses of the antigen. Administration of the adenoviral proteins in very low doses $(5-100 \mu \mathrm{g} /$ dose) were also ineffective in inducing tolerance (not shown).

Adoptive transfer of tolerance. A total of eight naive sublethally irradiated Gunn rats were infused with splenic cell or gut lymphocyte suspensions from two rats in each of groups A and C. For each donor pair, two recipients received splenocytes, and two received donor gut wall lymphocytes. Adoptive transfer of the tolerance was seen only in the rats that received splenocytes from rats that had received adenoviral proteins (group A). After Ad-hBUGT 1 administration, these rats showed a metabolic effect similar to that observed in the tolerized rats from group A (Fig. 8). Moreover, these rats exhibited either no antibody response or only a low titer of antiadenovirus neutralizing antibodies. In contrast, when group A donor gut wall lymphocytes were used, adoptive transfer of the tolerance did not occur. In the recipients of cells from BSA-fed rats (group C), a marked antiadenoviral humoral and cellular immune response occurred, and the transgene effect disappeared within 6 wk of the injection. Reinjection of the virus in these rats did not have any hypobilirubinemic effect.

\section{Discussion}

Previous experiments have shown that recombinant adenoviral vectors have the required efficiency to transduce a sufficient number of quiescent hepatocytes in vivo to correct the

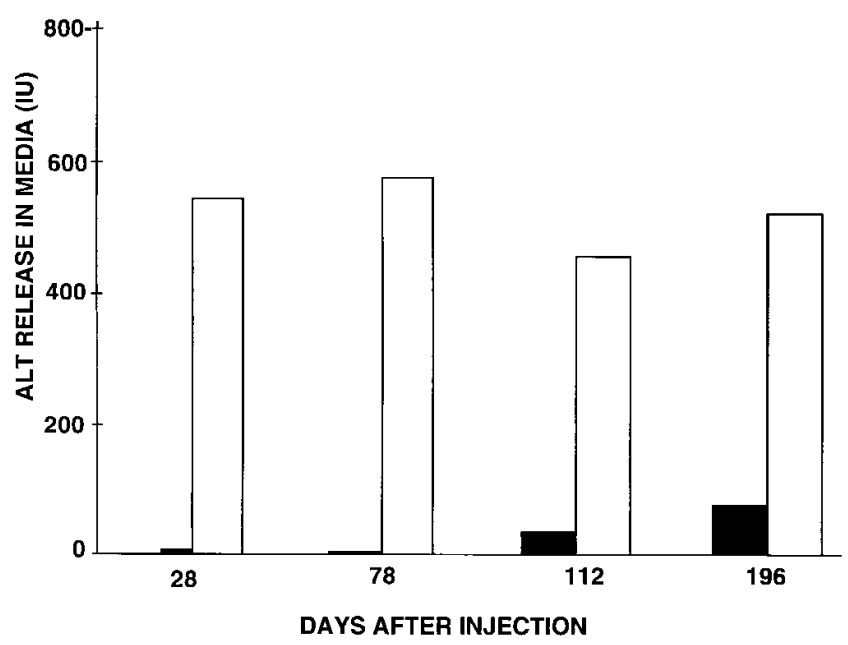

Figure 6. Effect of tolerization on CTL assay in group A tolerized rats (solid bars) and group C control (open bars) rats. T cells were harvested after each injection from two rats in each group and were used as effector cells against adenovirus infected primary hepatocytes. CTL activity was expressed as ALT levels released from adenoviral infected hepatocytes, as decribed in the materials and methods. Marked CTL activity was observed in rats from group $\mathrm{C}$ but not in rats from group A. 
metabolic deficiency in Gunn rats $(2,5)$. However, the usefulness of adenoviral vectors is limited by both humoral and cellmediated antiadenoviral responses that limit the duration of expression transgenes introduced in vivo via adenoviral vectors. The CTL response that clears the adenovirally infected cells is thought to require viral gene transcription, and may not be found after injection of ultraviolet-irradiated inactivated viruses $(30,31)$. In cases where the transgene expression product is immunogenic in the recipient, immune response against the transgene product may also limit the duration of gene expression (32). Furthermore, the sensitized CTLs mediate hepatic inflammation after subsequent injections of the virus. Antiadenoviral neutralizing antibodies that appear in response to adenoviral proteins prevent effective gene transfer upon subsequent injections of the recombinant adenovirus $(10,32,33)$. Studies in nude and SCID mice with defects in $\mathrm{T}$ or both $\mathrm{T}$ and $\mathrm{B}$ cell functions, as well as the use of several immunosupressive regimens including cyclosporine and cyclophosphamide, have shown that a longer duration of gene expression occurs in states of systemic immunosuppression $(10,34,35)$. However, the potential for clinical application of these methods is clearly

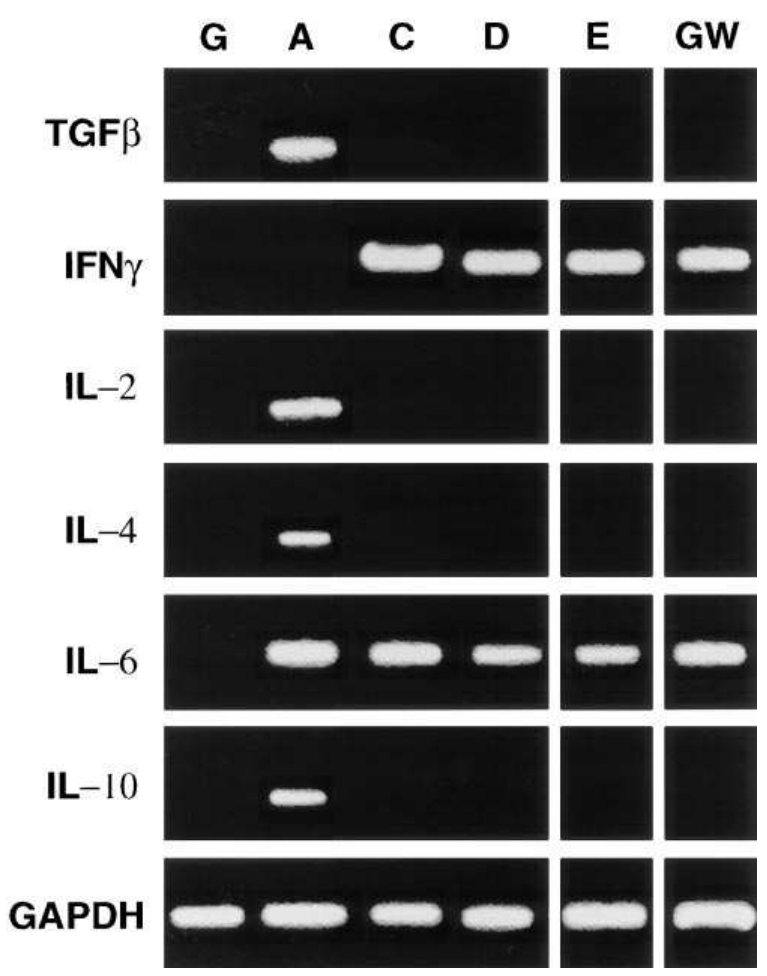

Figure 7. RT-PCR for rat cytokines. Amplification products of RTPCR on RNA extracted from splenocytes from the various groups on day 101 is shown. Positive bands for IL-2, IL-4, IL-10, and TGF $\beta_{1}$ were found only in the splenocytes from rats orally tolerized by administration of adenoviral proteins at $1 \mathrm{mg} / \mathrm{d}$ (group A). In contrast, splenocytes from rats that were fed BSA, (group C), no proteins (group D) or 50-100 mg/d adenoviral proteins (group E), as well as gut wall lymphocytes, and normal untreated Gunn rats $(G)$ were negative for these four cytokines. IFN $\gamma$ was negative by RT-PCR in naive rats $(G)$ and in rats from group A, but positive in groups C, D, E, and GW. IL-6 was found to be positive in all four experimental groups, but not in control Gunn rats tested, and probably behaves as nonspecific acute phase reactant. Rat glyceraldehyde dehydrogenase was used as a control for the RNA templates. limited. In contrast, induction of specific tolerance to recombinant adenoviruses could allow long-term gene expression leaving the general immunological defense of the recipient intact $(5,36)$. In this study we have demonstrated that tolerance against adenoviral antigens can be achieved by feeding rats with adenoviral structural proteins, thus allowing repeated injections of the recombinant virus and permitting long-term correction of a genetically transmitted metabolic defect. Although for administering precise doses we have used duodenostomy tubes to introduce the adenoviral proteins, for potential clinical application the proteins can be conveniently administered orally.

Oral tolerance is a recognized procedure for induction of antigen-specific peripheral immune tolerance (12). Several studies have shown that both in animals and humans it is possible to induce tolerance against a variety of antigens by feeding the host with those antigens (37-39). Oral administration of autoantigens has been shown also to prevent or alleviate several autoimmune disorders such as collagen-induced arthritis and experimental allergic encephalomyelitis in animals, and has been used with some success in humans for the treatment of rheumatoid arthritis and multiple sclerosis $(37,38)$. Several mechanisms are involved in inducing systemic immunologic hyporesponsiveness by oral antigen feeding. Orally administered antigens may induce active immune suppression, clonal anergy or clonal deletion (38-42). The mechanism of tolerance depends mainly on the dose of the antigen. Lower doses induce tolerance through the appearance of negative immunoregulatory cells, whereas higher doses lead to clonal inactivation (12).

Both CD4 and CD8 lymphocytes that can be typed as either TH1 cells that produce IL-2 and IFN $\gamma$, or TH2 cells that produce IL-4, IL-5, and IL-10 can help immunoglobulin production and isotype switching (40-42). Th1 and Th2 cells crossregulate each other by the release of IFN $\gamma$ and IL-10. Mucosal Th2-like cells are unique in their ability to produce $\mathrm{TGF}_{1}$ as well as Th2 cytokines (42-44). Classically these cells have been generated by intermittent feeding with low doses of antigen

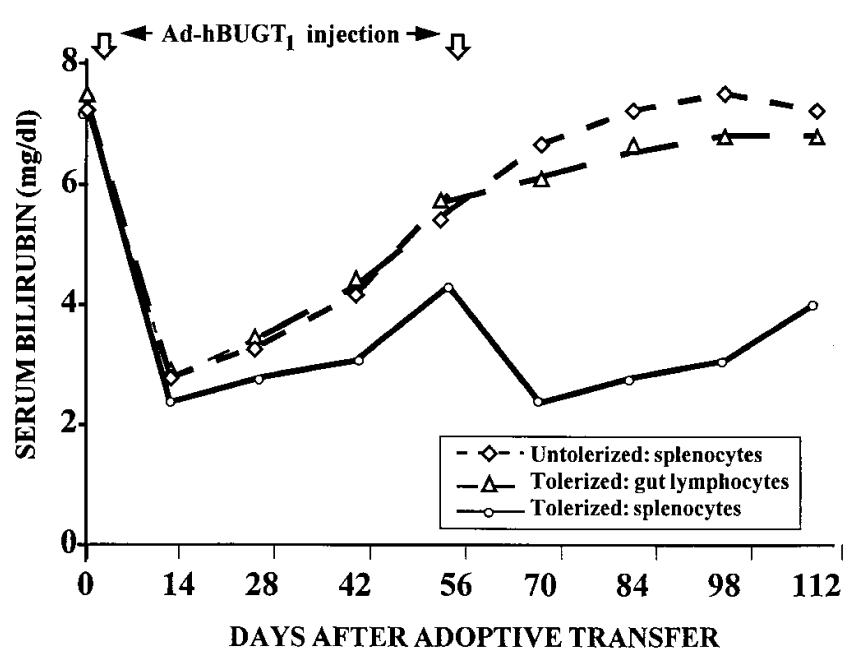

Figure 8. Effect of adoptive transfer of tolerance on serum bilirubin levels in irradiated naive rats transplanted with splenocytes from orally tolerized rats from group A $(S)$, gut wall lymphocytes from the the same animals, and splenocytes from control, BSA-fed rats from group $\mathrm{C}(C)$. Rats were injected after splenocyte transplantation with the recombinant adenovirus twice, on days 1 and 56 . 
and are responsible for the antigen-specific suppresser activity as well as the bystander tolerance observed after low dose feeding (43-45). Administration of anti-TGF $\beta_{1}$ has been shown to abrogate oral tolerance in several model systems (43-46). In contrast, feeding of higher doses of antigen results in induction of anergy of antigen-specific Th1 cells leaving the humoral response intact. In some model systems, anergy of Th2 cells occurs as well $(14,47)$. This anergy can be at least partially reversed by administration of IL-2, although eventually, apoptosis of antigen-specific cells may occur (47).

The results of the present study, show that administration of low-dose viral proteins achieved long-lived tolerance, while administration of larger doses failed to induce it. These results with low-dose feeding favor tolerance induction by an active suppressive mechanism resulting in bystander tolerance to other immunogenic epitopes within the wild type virus. Adoptive transfer of the tolerance by transplantation of immune cells from tolerized donors to sublethally irradiated recipients further supports the existence of suppressor cells in this setting. Furthermore, as demonstrated for a variety of oral tolerance models, this suppression was associated with the development of antigen-specific $\mathrm{T}$ cells secreting $\mathrm{Th} 2$ cytokines and TGF $\beta(43-45,48)$. In addition, there was marked downregulation of IFN $\gamma$ production. Such inhibition of IFN $\gamma$ production is known to enhance oral tolerance as measured by in vitro hyporesponsiveness of $\mathrm{T}$ cells after secondary in vivo challenges (39-41, 44-45). In our study, oral administration of low-dose adenoviral major antigens led to down-regulation of both cellular and humoral arms of the antiviral immune response. Antiadenoviral antibodies did not develop in the vast majority of the rats, and the CTL killing activity of virally infected cells was significantly depressed. This is in accordance with recent studies that have shown that low dose oral tolerance can suppress both arms of the immune system (39, 40, 47-49).

It is of interest that the suppressive Th2 cells were found to be present in the spleens of tolerized animals, but not in the gut wall. Although a larger number of splenocytes were used for the adoptive transfer experiments, previous reports indicate that the number of gut wall lymphocytes used would have been sufficient to produce active tolerance, had there been suppressor cells in this population $(49,50)$. The fact that we did not observe inhibitory cytokine secretion from gut wall lymphocytes, as well as the failure of gut wall lymphocytes to adoptively transfer tolerance is probably due to the delay between the end of the feeding and cell extraction. This is consistent with the hypothesis that the memory for the tolerance resides in the spleen or other lymphoid organs, while the bowel cells serves as a vehicle for antigen presentation, processing and education of the suppressor regulatory cells (51-53).

Our results with high-dose antigen feeding suggest that viral protein extracts are insufficient to induce tolerance to the recombinant virus when the mechanism of tolerance is anergy rather than suppression. In this group of animals, adenoviral proteins were subsequently able to elicit production of IFN $\gamma$ in vitro. This suggests that $\mathrm{T}$ cells anergized by adenoviral proteins had this anergy reversed by administration of wildtype virus that contains additional immunogenic viral epitopes. Such reversal of anergy has been demonstrated in vitro when anergized cells are pulsed with IL-2. Experiments are currently underway to test this hypothesis.

Oral tolerization prolonged the transgene expression, as shown by the longer duration of the hypobilirubinemic effect.
However, the effect was not permanent, as indicated by the gradual increase of serum bilirubin levels between day 14 and 98 after the first Ad-hBUGT 1 injection. A similar decay of transgene effect was seen after induction of central tolerance to recombinant adenoviruses induced by injection of the virus during the newborn period (5). The decline of transgene effect seems to have resulted from the degradation of the episomal adenoviral DNA, rather than the loss of tolerance, because there was no antiviral CTL activity in the host during this period.

In conclusion, the present study shows the potency of low dose oral viral antigen administration in downregulating the antiviral immune response. This mode of tolerance induction is probably mediated by negative immunoregulatory cells secreting several inhibitory cytokines. This method has the potential to be used in clinical practice to tolerize the host to a useful recombinant adenovirus, and opens the possibility of providing effective long-term gene therapy for inherited metabolic diseases using these vectors.

\section{Acknowledgments}

This work was supported in part by the following National Institutes of Health grants: ROI-DK 46057 (to J. Roy Chowdhury); RO1-DK 39137 (to N. Roy Chowdhury), P30-DK 41296 (Liver Research Core Center), and the Core Cancer Research grant (M.S. Horowitz). Y. Ilan was supported by the NIH Hepatology Training Grant T32DK07218. Additional support was provided by the Gene Therapy Core of the Seaver Institute of Human Genetics of the Albert Einstein College of Medicine.

\section{References}

1. Ali, M., N.R. Lemoine, and C.J.A. Ring. 1994. The use of DNA viruses as vectors for gene therapy. Gene Ther. 1:367-384.

2. Jaffe, H.A., C. Danel, and G. Longenecker. 1992. Adenovirus-mediated in vivo gene transfer and expression in normal rat liver. Nat. Genet. 1:372-378.

3. Wilson, J.M., D.M. Jefferson, J. Roy Chowdhury, P.M. Novikoff, D.M. Johnston, and R.C. Mulligan. 1988. Retrovirus mediated transduction of adult hepatocytes. Proc. Natl. Acad. Sci. USA. 85:3014-3018.

4. Graham, F.L., and L. Prevec. 1991. Manipulation of adenovirus vectors. In Methods in Molecular Biology. E.J. Murray, editor. The Humana Press, Clifton, NJ. 109-128.

5. Takahashi, M., Y. Ilan, N. Roy Chowdhury, J. Guida, M.S. Horwitz, K Sengupta, and J. Roy Chowdhury. 1996. Long term correction of bilirubin UDP transferase I deficiency in Gunn rats by administration of a recombinant adenovirus during the neonatal period. J. Biol. Chem. 271:26536-26542.

6. Horwitz, M.S. 1990. Adenovirudae and their replication. In Virology. B.N. Fields and D.M. Knipe, editors. Raven Press, New York. 1679-1721.

7. Prevec, L., M. Schneider, K.L. Rosenthal, L.W. Belbeck, J.B. Derbyshire, and F.L. Graham. 1989. Use of human adenovirus-based vectors for antigen expression in animals. J. Gen. Virol. 70:429-434.

8. Yang, Y., Q. Li, H.C.J. Ertl, and J.M. Wilson. 1995. Cellular and humoral immune responses to viral antigens create barriers to lung-directed gene therapy with recombinant adenoviruses. J. Virol. 67:2004-2015.

9. Bett, A.J., L. Prevec, and F.L. Graham. 1993. Packaging capacity and stability of human adenovirus type 5 vectors. J. Virol. 67:5911-5921.

10. Yang, Y, F.A. Nunes, K. Berencsi, E. Gonczol, J.F. Engelhardt, and J.M. Wilson. 1994. Inactivation of E2a in recombinant adenoviruses improves the prospect for gene therapy in cystic fibrosis. Nat. Genet. 7:362-369.

11. Engelhardt, J.F., X. Ye, B. Doranz, and J.M. Wilson. 1994. Ablation of $\mathrm{E}_{2 \mathrm{a}}$ in recombinant adenovirus improves transgene persistence and decreases inflammatory response in liver. Proc. Natl. Acad. Sci. USA. 91:6196-6200.

12. Weiner, H. 1994. Oral tolerance. Proc. Natl. Acad. Sci. USA. 91:1076210765.

13. Vandenback, A.A., M. Vainiene, B. Clenik, G.A. Hashmin, A. Buenafe, and H. Offner. 1994. Definition of encephalitogenic and immunodominant epitopes of guinea pig myelin basic protein in Lewis rats tolerized neonatally with Gp-BP or Gp-BP peptides. J. Immunol. 153:852-859.

14. Hirahara, K., T. Hisatsune, K. Nishijima, H. Kato, O. Shiho, and S. Kaminogawa. 1995. CD4 T cells anergized by high dose feeding establish oral tolerance to antibody responses when transfered in SCID and nude mice. J. Immunol. 154:6238-6245. 
15. Roy Chowdhury, J., N. Roy Chowdhury, C.N. Falancy, R.R. Tephly, and W. Arias. 1986. Isolation and characterization of multiple forms of rat liver UDP-glucuronide glucuronsyltransferase. Biochem. J. 233:827-837.

16. Roy Chowdhury, J., P.M. Novikoff, N. Roy Chowdhury, and A.B. Novikoff. 1985. Distribution of UDP-glucuronsyltransferase in rat tissue. Proc. Natl. Acad. Sci. USA. 82:2990-2994.

17. Crigler, J.F., and V.A. Najar. 1969. Congenital familial nonhemolytic jaundice with kernicterus. Pediatrics. 10:169-180.

18. Bosma, P.J., N. Roy Chowdhury, B.G. Goldhorn, M.H. Hofker, R.P.J. Elferink, P.L.M. Jansen, and J. Roy Chowdhury. 1992. Sequence of exons and the flanking regions of human bilirubin UDP-glucuronsyltransferase gene complex and identification of a genetic mutation in a patient with Crigler-Najjar syndrome, type 1. Hepatology. 15:941-947.

19. Ritter, J.K, J.M. Crawford, and I.S. Owens. 1991. Cloning of two human liver bilirubin-Dý UDP-Glucuronosyltransferase cDNAs with expression in COS-1 cells. J. Biol. Chem. 266:1043-1047.

20. Bosma, P.J., J. Seppen, B. Goldhoorn, C. Backer, O. Elferink, J. Roy Chowdhury, N. Roy Chowdhury, and P. Jansen. 1994. Bilirubin UDP-glucuronosyltransferase- 1 is the only relevant bilirubin glucuronidating isoform in man. J. Biol. Chem. 269:17960-17964.

21. Horwitz, M.S., M.D. Scharff, and J.V. Maizel. 1969. Synthesis and assembly of Adenovirus 2: Polypeptide synthesis, assembly of capsomeres and morphogenesis of the virion. Virology. 39:682-694.

22. Mazel, J.V., D.O. White, and M.D. Scharf. 1968. The polypeptides of adenovirus: Soluble proteins, cores, top components and the structure of the virion. Virology. 36:126-136.

23. Wang, A.M., M.V. Doyle, and D.F. Mark. 1989. Quantitation of mRNA by the polymerase chain reaction. Proc. Natl. Acad. Sci. USA. 86:9717-9721.

24. Peters, W.H.M., P.L.M. Allebes, L.G. Jansen, and P.J.A. Capel. 1987. Characterization and tissue specificity of a monoclonal antibody against human uridine 5'-diphosphatase-glucuronosyltransferase. Gastroenterology. 93:162-169.

25. Towbin, H., T. Staehlin, and J. Gordon. 1979. Electrophoretic transfer of proteins from polyacrylamide gels to nitrocellulose sheets: Procedure and some applications. Proc. Natl. Acad. Sci. USA. 76:4350-4354.

26. Trotman, B.W., J. Roy Chowdhury, and G.D. Wirt. 1982. Azodipyroles of unconjugated and conjugated bilirubin using diazotized ethyl anthranilate in dimethyl sulfoxide. Anal. Biochem. 121:175-180.

27. Roy Chowdhury, J., N. Roy Chowdhury, G. Wu, R. Shouval, and I.M. Arias. 1981. Bilirubin mono and diglucoronide formation by human liver in vitro: Assay by high pressure liquid chromatography. Hepatology. 1:622-627.

28. Seglen, P.O. 1976. Preparation of isolated rat liver cells. Methods Cell Biol. 13:29-83

29. Taguchi, T., W.A. Archer, K. Fuijihashi, M. Yamamoto, J. McGee, J.A. Bluestone, and H. Kiguno. 1991. Novel function of intestinal intraepithelial lymphocytes. J. Immunol. 147:3736-3744.

30. Cotten, M., M. Saltik, M. Kursa, E. Wagner, G. Maas, and M.L. Birnstiel. 1994. Psoralen treatment of adenovirus particles eliminates virus replication and transcription while maintaining the endosomolytic activity of the virus capsid. Virology. 205:254-261.

31. Cotten, M., E. Wagner, K. Zaloukal, S. Phillips, D.T. Curiel, and M.L. Birnstiel. 1992. High efficiency receptor-mediated delivery of small and large gene constructs using the endosome-disruption activity of defective or chemically inactivated adenovirus particles. Proc. Natl. Acad. Sci. USA. 89:6094-6098.

32. Dai, Y., E.M. Schwarz, D. Gu, W.W. Zhang, and N. Sarvetnick. 1995. Cellular and humoral immune responses to adenoviral vectors containing facctor IX gene: tolerization of factor IX and vector antigens allows for long term expression. Proc. Natl. Acad. Sci. USA. 92:1401-1405.

33. Yang, Y, H.C.J. Ert, and J.M. Wilson. 1994. MHC Class I restricted cytotoxic $\mathrm{T}$ lymphocytes to viral antigens destroy hepatocytes in mice infected with E1 deleted recombinant adenoviruses. Immunity. 1:433-442.
34. Ilan, Y., N. Roy Chowdhury, V. Jona, A. Davidson, M. Horwitz, and J. Roy Chowdhury. 1996. Transient short term FK-506 treatment permits long term gene expression using recombinant adenovirus vectors. J. Hepatol. 25:73A (Abstr.).

35. Yang, Y., G. Trinchieri, and J.M. Wilson. 1995. Recombinant IL-12 prevents formation of blocking IgA antibodies to recombinant adenovirus and allows repeated gene therapy to mouse lung. Nat. Genet. 11:211-214.

36. Ilan, Y., P. Attvar, M. Takahashi, A. Davidson, M. S. Horwitz, J. Guida, N. Roy Chowdhury, and J. Roy Chowdhury. 1996. Induction of central tolerance by intrathymic inoculation of adenoviral antigens into the host thymus permits long-term gene therapy in Gunn rats. J. Clin. Invest. 98:2640-2647.

37. Javed, N.H., I.E., Gienapp, K.L. Cox, and C.C. Whitcare. 1995. Exquisite peptide specificity of oral tolerance in experimental autoimmune encephalomyelitis. J. Immunol. 155:1599-1605.

38. Khare, S.D., C.J. Krco, M.M. Griffiths, H.S. Luthra, and C.S. David. 1995. Oral administration of an immunodominant human collagen peptide modulates collagen induced arthritis. J. Immunol. 155:3653-3659.

39. Chen, Y., J.I. Inobe, and H. Weiner. 1995. Induction of oral tolerance to myelin basic protein in CD8 depleted mice: Both cells mediate active response. J. Immunol. 155:910-916.

40. Husby, S., J. Mestecky, Z. Moldoveanu, S. Holland, and C.O. Elson. 1994. Oral tolerance in humans: $T$ cell but not B cell tolerance after antigen feeding. J. Immunol. 152:4663-4668.

41. Garside, P., M. Steel, F. Liew, and A. Mowat. 1995. CD4 but not CD8 cells are required for the induction of oral tolerance. Intern. Immunol. 7:501-504.

42. Chen, Y., J. Inobe, and H.L Weiner. 1995. Induction of oral tolerance to MBP in CD8 depleted mice. J. Immunol. 155:910-916.

43. Miller, A., O. Lider, A.B. Roberts, M. Sporn, and H. L. Weiner. 1992. Suppressor $\mathrm{T}$ cells generated by oral tolerance to myelin basic protein suppress both in vitro and in vivo immune responses by the release of TGF $\beta$ following antigen specific triggering. Proc. Natl. Acad. Sci. USA. 89:421-425.

44. Hancock, W., M. Polansli, J. Zhang, N. Blogg, and H. Weiner. 1995. Suppression of insulitis in NOD mice by oral insulin administration is associated with selective expression of IL-4-10, TGF- $\beta$ and prostaglandine-E. Am. J. Pathol. 147:1193-1197.

45. Santos, L.M.B., A. Al-Sabbagh, A. Londono, and H.L. Weiner. 1993. Oral tolerance to myelin basic protein induces TGF $\beta$ secreting $T$ cells in Peyer's patches. J. Immunol. 150:115A.

46. Fontana, A., D.K. Sonstan, K. Frei, U. Malipiero, and H. Pfister. 1992. Modulation of the immune response by TGFß. Int. Arch. Allergy Immunol. 99: $1-7$.

47. Weiner, H. 1995. Oral tolerance: Mobilizing the gut. Hosp. Pract. 30: 53-58.

48. Fuss, I., B. Kelsall, W. Strober, and M. Neurath. 1996. TNBS-induced experimental granulomatous colitis in mice is abrogated by the induction of TGF $\beta$ mediated oral tolerance. Gastroenterology. 110:912A.

49. Chen, Y.H., and H.L. Weiner. 1996. Dose dependent activation of antigen-specific T cells following oral tolerance. Ann. NY Acad. Sci. 778:111-121.

50. Friedman, A. 1996. Induction of anergy in TH1 lymphocytes by oral tolerance: Induction of antigen dosage and frequency of feeding. Ann. NY Acad. Sci. 778:103-110.

51. Lee, H.O., S.D. Hurst, and T.A. Barret. 1996. Antigen specific T cell responses to intragastric or intravenous antigen administration. Gastroenterology. 110:409A.

52. Poussier, P., and M. Julius. 1995. T-cell development and selection in the intestinal epithelium. Semin. Immunol. 7:321-326.

53. Fujhashi, K., S. Kahabata, T. Hiroi, and M. Yammoto. 1996. Interleukin 2 and interleukin 37 reciprocally induce IL-7 and IL-2 receptors on T-cell receptor positive intraepithelial lymphocyte. Proc. Natl. Acad. Sci. USA. 93:36133618 . 